\title{
OBITUARY: Sir Stephen Egerton
}

Sir Stephen Egerton, who died of cancer on 7 September 2006, was President of the Society from 1994 to 1998. Born on 21 July 1932, he was educated at Eton and, after National Service in the army, at Trinity College Cambridge. A classicist and a man of culture, he was interested in archaeology from his schooldays. He joined the Foreign Service in 1956 and was sent to study Arabic at the language school run by the Foreign Office in Lebanon. His first assignment was as a political officer in Kuwait, which at that time was still a semicolonial regime in which he doubled as court registrar.

He got to know Libya in 1972-3 as Counsellor and Head of Chancery in the Embassy in Tripoli in the early days of the revolution. With the successful diplomat's knack of being in the right place at the wrong time, he was the Undersecretary in charge of Libyan affairs in the Foreign Office in 1984 when the murder of WPC Yvonne Fletcher in St James Square led

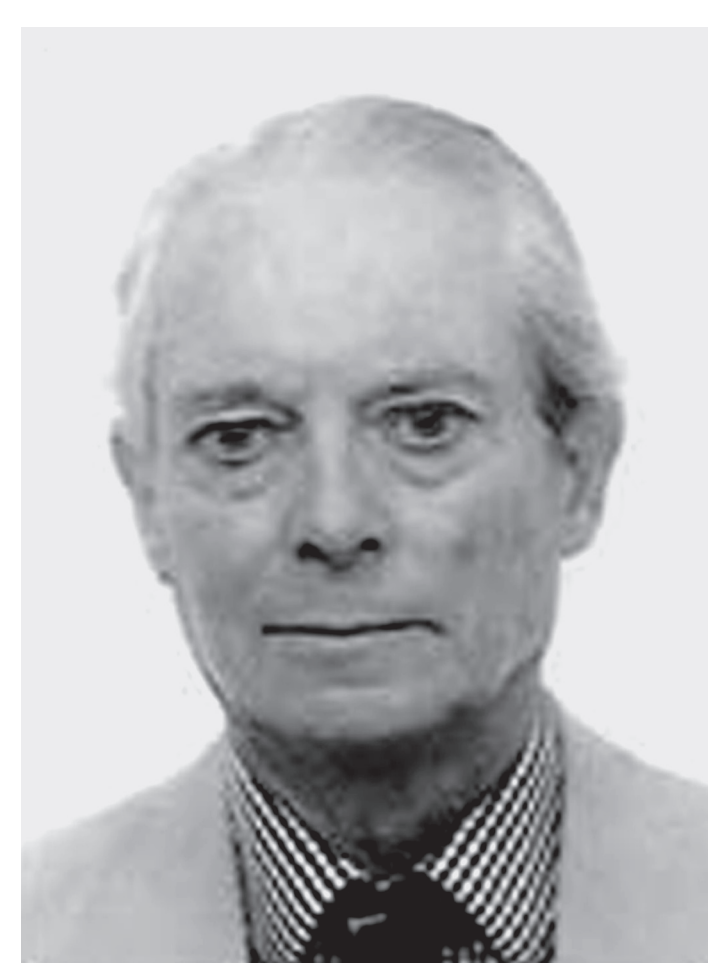

Sir Stephen Egerton Britain to break off diplomatic relations. In the absence of the Prime Minister and Foreign Secretary abroad he had the tricky task of guiding an inexperienced ministerial team through an affair which could easily have gone even further wrong.

The Arab world was the main theme of his foreign service career. Although he had his share of work in Whitehall he preferred the independent responsibility of work overseas. At the British mission to the UN in 1967 he played a part in the drafting of the famous Security Council resolution 242, the basis since then of attempts to make peace between Israel and the Arabs. Before going to Libya he had already served four years in Baghdad, and he returned there on his first appointment as Ambassador, which involved encounters with Saddam Hussein and the horrors of the Iraq-Iran war. Having served earlier as Consul General in Rio de Janeiro he was disappointed of an appointment as Ambassador to Mexico; the pressure was always on Arabists of his quality to return to the Middle East, and instead he went to Saudi Arabia. Riyadh by now rivalled or replaced Cairo as the summit of the ambitions of the diplomatic Arabist, but Egerton went on to return to his classical roots as Ambassador in Rome. He also had the exotic responsibility of becoming the first British Ambassador to Albania in the post-Hoxha era.

In retrospect the years of his Presidency of the Society can be seen to have been a period when Libya and Anglo-Libyan relations were slowly returning to normal, a process in which the 
Society had its part to play. Egerton's guidance through the diplomatic jungle was invaluable. He was frustrated that the one thing he could not do was ask to accompany one of the Society's archaeological missions on a dig. "Whenever I talk wistfully about revisiting Libya, they shove a brochure into my hand and say that the $£ 2,500$ trip to the antiquities on the littoral is good value!"

The Society was but one of a varied palette of activities embracing politics, business, culture and religion in which Egerton engaged following his retirement from the diplomatic service in 1992. For the first ten years he was a consultant to Enterprise Oil, at that time the largest independent British oil exploration and development company, active in the North Sea, the Gulf of Mexico and Norway. A committed member of the Church of England, he was a director and later trustee of St Andrew's Trust at Lambeth Palace working with churches in the former Soviet Union, and he was also much involved with Norwich Cathedral. He was a vice-president of the British School of Archaeology in Iraq, and a vice-chairman of the Keats-Shelley Memorial Association which runs the Memorial house at the foot of the Spanish Steps in Rome. He also held various offices in the Bristol Institute of Hellenic and Roman Studies, founded in 2000 to promote research into Greco-Roman culture both ancient and modern, and in the Venice in Peril fund.

He was a signatory and an enthusiastic supporter of the letter of the 52 retired Ambassadors to the Prime Minister about policy in Palestine and Iraq in 2004, though it gave him a few difficulties locally: "When in Norfolk, I realise I have to tread like Agag! One cannot afford to offend anyone when living in the deep country." Scarcely a month before he died he chaired a session at Chatham House on the Iraq war, to which he was profoundly opposed.

He was a man of strong feelings, not always concealed by his conventional and correct style. An astute user of words, he must have known that his habit of addressing male friends and acquaintances as "my dear", or sometimes to those of very senior military rank "darling", could be disconcerting to those unfamiliar with the courtesies of Arabia. His humour, energy and charm engaged and retained a large circle of friends.

He was married for forty-eight years to Caroline née Cary-Elwes, who was awarded an O.B.E. in 2002 for her services to the British School at Rome. He is survived by her and by one son and one daughter.

\section{Oliver Miles}

